\title{
The Security of the Visegrad Group Countries in the Light of Interests of the European Union and the Remaining Member States
}

\begin{abstract}
The aim of the presented paper is to depict the approach of the European Union and its member states towards security in the countries belonging to the Visegrad Group. For V4 countries it is vital to implement such a policy that would make Western Europe aware of the threat and exert political pressure on the countries of the so-called old Union (in particular on France and Germany) to assume a greater responsibility for security and peace in the world as an international organisation and support all actions designed to establish real and effective common defence policy of the EU. Indeed, state security is presently ensured not only by the armed forces of a given country but also through the assurance of obtaining effective assistance (of different kind) from other states and international organisations guaranteed by international agreements.
\end{abstract}

Keywords:

security, Visegrad Group, European Union, state security, common defence policy, V4 Defence Cooperation

When the Second World War ended efforts were taken to prevent an occurrence of similar conflicts in Europe in the future. Several states of Western Europe initiated a project whose name may wrongly indicate, and indeed often does, that the cooperation proposed at that time was of an economic character and began an interaction aimed at changing the difficult economic situation in post-war

1 Nicolaus Copernicus University in Toruń, Department of European Law. Poland; E-MAIL: kwch@umk.pl.

2 Nicolaus Copernicus University in Toruń, Department of Constitutional Law. Poland; E-MAIL: mserowaniec@umk.pl. 
Europe. Meanwhile, the Schuman Declaration made it clear that the new project was of political nature, with its main objective consisting in ensuring peace and hence - security in Europe. Let us not forget that coal and steel were strategic raw materials at that time (as opposed to today's natural gas and oil) and history had already given two painful lessons showing that when in the past Germany had an unrestricted access to coal and steel (due to the deposits of the Ruhr and Saarland Districts) and no-one (i.e., mainly the international community of that time) had an effective control on their extraction, it always led to the militarisation of that country and, in consequence, to bloody and cruel wars in Europe. Moreover, electrifying news appeared on the horizon concerning efforts made by scientists on both sides of the Atlantic aimed towards controlled use of nuclear energy, also for military purposes. Thus, the project which was to guarantee peace and safety to the largest possible part of Europe assumed an internationalisation of the control of extraction and use of the then strategic raw materials by several Western European countries involved in mutual cooperation.

Therefore, no matter the assumed perspective, the idea was visionary and bold, with strictly political character, however it often used to be presented, and still sometimes is, as an economic project, and consequently the public awareness often wrongly identifies the two main reasons for the establishment of the European Coal and Steel Community in 1952 and of EURATOM in 1958 as economic and not political, although their undertones were mainly political and oriented at peace and security preservation, involvement of the thus far isolated Germany in international cooperation and finding a common European concept of cooperation to provide counterbalance for the USSR on one side and the USA on the other. At that time the member states of today's Visegrad Group, due to post-war system of forces, were excluded from the opportunities that the idea of European integration offered to Western Europe. The division of Europe with the Iron Curtain caused the countries of our interest - although not as Soviet republics - to remain in the sphere of Soviet influences, and their security - as a response to the establishment and actions of NATO - was to be guarded by the Pact of Friendship, Cooperation and Mutual Assistance, i.e., the Warsaw Pact. The events of late 1980s in Poland and early 1990s alongside the collapse of the Soviet Union opened to those countries the possibility to take independent decisions regarding their accession to international organisations, including political-military ones, which had thus far been restricted due to political reasons. Hence, the beginning of democratic transformations in the countries of Central-Eastern Europe, the German Reunification and the breakdown of the Soviet Union caused the countries, which until then could not truly and sovereignly decide on their security, to face decisions that they 
finally could and wanted to made independently. Let us add that at this point they found themselves greatly delayed at the point of development where the countries of Western Europe had already spent more than half a century. The leaders of the member states of the European Communities of the time, on the other hand, again had to take a decision on new directions of European integration and again the area where important determinations had to be made concerned aspects connected with politics and security.

The first important step towards an inclusion of the term security expressis verbis into the Community law consisted in the establishment of the European Union and its second pillar, namely the Common Foreign and Security Policy. This pillar was characterised by significant diversities within the decision-making procedures. As opposed to the first pillar - the community pillar, it was a principle of CFSP to take decisions with the use of the so-called intergovernmental and not the Community method. Until present, the decision-making procedures in this area are of a special nature which bears particular political consequences (Witkowska-Chrzczonowicz, 2016, p. 42).

It was not until the Treaty of Lisbon that the pillar structure of the EU was changed - besides the visible organisational-institutional changes it did not in fact create the basis for a more practically effective (through the implementation of new revolutionary decision-making methods) common foreign and security policy.

Also current legal regulations of the EU of a treaty status do not leave any doubt that one of the main objectives of the EU is supporting peace and prosperity of nations combined with supporting the values constituting the Union (Banaszak, 2014, p. 10). In the currently effective version of the Treaty on European Union, the word 'security' appears as many as four times only in two neighbouring paragraphs of the preamble, with more references to security appearing throughout the content ("resolved to implement a common foreign and security policy including the progressive framing of a common defence policy, which might lead to a common defence in accordance with the provisions of Article 42, thereby reinforcing the European identity and its independence in order to promote peace, security and progress in Europe and in the world, resolved to facilitate the free movement of persons, while ensuring the safety and security of their peoples, by establishing an area of freedom, security and justice, in accordance with the provisions of this Treaty and of the Treaty on the Functioning of the European Union”). Article 3 Sec. 2 of the TEU, on the other hand, provides that "the Union shall offer its citizens an area of freedom, security and justice without internal frontiers, in which the free movement of persons is ensured in conjunction with appropriate 
measures with respect to external border controls, asylum, immigration and the prevention and combating of crime," and Article 3 Sec. 5 TEU: "In its relations with the wider world, the Union shall uphold and promote its values and interests and contribute to the protection of its citizens. It shall contribute to peace, security, the sustainable development of the Earth, solidarity and mutual respect among peoples, free and fair trade, eradication of poverty and the protection of human rights, in particular the rights of the child, as well as to the strict observance and the development of international law, including respect for the principles of the United Nations Charter.” Thus, the guaranteed support for widely understood security, which is repetitively stressed in Art. 3 TEU where the main objectives of the EU and common values of the member States are accumulated, confirms that security remains one of the priorities of the EU.

Nonetheless, it is worth noting that Art. 4 Sec. 2 TEU which designates certain limits to the EU's interference stipulates that "the Union shall respect the equality of Member States before the Treaties as well as their national identities, inherent in their fundamental structures, political and constitutional, inclusive of regional and local self-government. It shall respect their essential State functions, including ensuring the territorial integrity of the State, maintaining law and order and safeguarding national security. In particular, national security remains the sole responsibility of each Member State.” It is quite a characteristic treaty provision once we consider the fact of a strengthening political and economic relationship as well as constant, irreversible (or difficult to reverse) process of standardisation (and not only harmonisation) of law in multiple areas. A question should be raised whether it is even feasible to separate national security from the security of the states of the European Union as a whole? Some EU member states (including all the states of the discussed Visegrad Group) simultaneously belong to the North Atlantic Treaty, however considering the degree of integration of the EU, it is difficult to accept the validity of the claim that the issue of security of the EU countries boils down to the status and relation to NATO or the status of a neutral state. The issue is much more complex.

In concord with Art. 42 of the Treaty on European Union, the common security and defence policy (CSDP), which constitutes an integral part of the common foreign and security policy (CFSP), provides the Union with operational capacity for peace-keeping and conflict prevention in accordance with the principles of the United Nations Charter and includes the progressive framing of a common Union defence policy which may lead to a common defence, when the European Council, acting unanimously, so decides. CSDP is realised on the basis of civilian and military capabilities of member states, with respect to the obligations resulting 
from the North Atlantic Treaty. It comprises elements introduced by the Treaty of Lisbon: mutual defence clause (Art. 42 Sec. 7 TEU), permanent structured cooperation within defence (Art. 42 Sec. 6 and Art. 46 TEU), solidarity clause in the event of a terrorist attack, natural disaster or human caused disaster (Art. 222 TEU). However, these mechanisms have not been equipped with suitable implementing rules.

Let us add that the so-called mutual defence clause from Art. 42 Sec. 7 TEU stipulates the following: "if a Member State is the victim of armed aggression on its territory, the other Member States shall have towards it an obligation of aid and assistance by all the means in their power, in accordance with Article 51 of the United Nations Charter," however "this shall not prejudice the specific character of the security and defence policy of certain Member States," and "commitments and cooperation in this area shall be consistent with commitments under the North Atlantic Treaty Organisation, which, for those States which are members of it, remains the foundation of their collective defence and the forum for its implementation." Source literature rightly points out that the clause of 'allied assistance in aggression' constitutes the most important treaty provision for Poland and simultaneously - unfortunately - it is fiction, as similarly to many other treaty clauses it is fortified by such limitations that they minimise or even trivialise their actual effect (Muszyński, 2016, p. 19).

It is a kind of a manifestation of 'political dissociated personality' to create on the one hand vast (and costly) diplomatic resources for the implementation of 'common' foreign and security policy in the form of the European External Action Service while on the other assume the position that in the case of one of the most important aspects of security - i.e., national security, each member state is in fact on its own and the Union law is constructed in such a way as to enable justification of such solitude even contrary to the principle of solidarity. Thus, the issue of quality and status of realisation of the said 'common' foreign and security policy not only in the context of the European Union as a whole but also the countries of the Visegrad Group should be an object of a sound analysis of the doctrine, and any actions consisting in undertaking scientific and practical discussion on those issues should be recognised as extremely valuable initiatives (Bień-Kacała \& Serowaniec, 2016, pp. 15-21). Of course, we need to emphasise that we are aware of the fact that today's security of the state is guaranteed not only by the military forces of that state but also by the possibilities ensured by international agreements to obtain effective assistance (of different kinds) from other countries (Szmulik, 2012, p. 4), hence membership in various international organisations constitutes a condition that influences it. We should add that in the context of their 
own security, the majority of countries in the world adopted a separate cooperation strategy (with other international law entities, most often with other countries) (Szmulik, 2012, p. 6).

Title V TEU “General provisions on the Union's external action and specific provisions on the common foreign and security policy" is also vital for our considerations. Art. 21 Sec. 2 it. a) defines Union's security protection as one of the objectives of determining and conducting common policies and actions as well as striving towards ensuring a high level of cooperation in all fields of international relations (similarly to it. c) specified by this article, which refers to 'the strengthening of national security'. On the other hand, pursuant to Art. 22 Sec. 1 TEU, "on the basis of the principles and objectives set out in Article 21, the European Council shall identify the strategic interests and objectives of the Union. Decisions of the European Council on the strategic interests and objectives of the Union shall relate to the common foreign and security policy and to other areas of the external action of the Union. Such decisions may concern the relations of the Union with a specific country or region or may be thematic in approach. They shall define their duration, and the means to be made available by the Union and the Member States. The European Council shall act unanimously on a recommendation from the Council, adopted by the latter under the arrangements laid down for each area."

This is an important provision of title V, as any important decisions encompassing common foreign and security policy must be made unanimously by the European Council, and - as follows - no country may fundamentally oppose such a decision, which is taken without the Chairperson of the European Council or the Chairperson of the European Commission, or the High Representative of the Union for Foreign Affairs and Security Policy. ${ }^{3}$ Thus, the decision making in this area strongly depends on current political situation.

On the one hand, subsequent provisions create an impression that such a 'common' foreign and security policy does exist and impose on the member states an obligation to support it 'without prejudice' and "in the spirit of mutual loyalty and solidarity.” However, on the other, they also impose numerous conditions on the decisions made within the said policy that are difficult to fulfil in the case of a really complex international problem thus, in fact, tying the Union's hands, making it as inoperative and non-dynamic as the UNO. Thus, it is hard to

3 See also Art. 31 Sec. 1 TEU. The other provisions of Art. 31 TEU also confirm that the decision-making procedures with regard to title V TEU are constructed in such a way that in the event of a lack of a common vision regarding a solution to a particular problem acceptable to all the states, a decision cannot be taken. This makes common foreign and security policy unreliable in terms of its efficacy in difficult or extreme situations. 
dismiss the feeling that despite the good intentions and ongoing efforts to establish a legal framework ensuring greater cohesion of the EU with regard to external actions, a lot remains to be achieved in this area.

Indeed, it is not entirely possible to reliably and consistently conduct any policy mainly - and unfortunately only - with the use of instruments and actions indicated in Art. 25 TEU: “a) defining the general guidelines, b) adopting decisions defining: (i) actions to be undertaken by the Union; (ii) positions to be taken by the Union; (iii) arrangements for the implementation of the decisions referred to in points (i) and (ii); and by (c) strengthening systematic cooperation between Member States in the conduct of policy."

The EU is an international (supranational) organisation which has thus far managed to successfully develop certain mechanisms, whereas other are still negatively verified. It is hard to expect effective actions or establishment of a legal framework for common foreign and security policy comparable with that of organisations of a radically different nature (as for instance NATO). In literature, the EU is characterised as a 'non-military power' (Milczarek, 2006, pp. 208-209). This statement must constitute a starting point for any further considerations and conclusions.

The Treaty of Lisbon undoubtedly moved Common Foreign and Security Policy and Common Security and Defence Policy to a 'higher level' in a sense that it gave it more coherent frames for the functioning as well as new institutional instruments which, in a better or worse way, try to be conducive to the deepening of certain aspects of cooperation, especially when it comes to security and foreign policy. However, what is disturbing is that EU politicians either do not see or choose not to see that these actions are insufficient. Underestimation of the threat resulting from neo-imperial policies of Russia, as well as the risk connected with rapidly growing enhancement of the influence of the Self-Proclaimed Islamic State in combination with rather inefficient legal instruments allowing the Union to react quickly and adequately may prove pernicious for it as a whole as well as for the security of its particular members and now is the time to realise that and implement adequate measures.

Therefore, new institutional mechanisms within Common Foreign and Security Policy are effective only to a certain extent. During the preparations of the Treaty of Lisbon these solutions seemed promising when it came to the transition from the unfavourable rotation-based presidency in the Council, which was negatively verified after years of its functioning. It appears, however, that the changes introduced by the Treaty of Lisbon created certain threats for the working of EU mechanisms, particularly since it was negotiated and adopted at the time of eco- 
nomic prosperity and none of its founders would have suspected that the TL was to become a treaty for the very hard times to come and enable the EU to give an adequate and effective response to such phenomena as, for instance, the war in Ukraine. It seems that the doctrine diagnosis stating that the sphere of the EU's external representation including the scope of CFSP required further regulation was correct. Nonetheless, the adopted reforms, an introduction of several centres, all of which aspire to play a vital role in this area, need to be evaluated negatively (Witkowska-Chrzczonowicz, 2014, p. 123), as it needs to be admitted that the EU lacks visible and strong leadership, perhaps with the exception of the informal tandem of "the chancellor of Germany - the president of France" that has been there for years and - as it seems - is bound to become even stronger after Brexit. Admittedly, for years Great Britain has hindered the strengthening of CSDP, e.g., by preventing establishment of permanent leadership for the EU's mission at the time of Polish presidency in 2011 or increasing the budget and scope of competences of the European Defence Agency (EDA), however at the same time it made a significant contribution to European operations (e.g., the EUNAVFOR Atalanta maritime mission) and development of military capabilities (the EU combat groups). Therefore, on the one hand Brexit puts an end to the British veto regarding acceleration of the EU's integration in defence, while on the other - constitutes a significant political and practical weakening of CSDP that calls into question its further existence in the current form. For this reason, already a few days after the British referendum, the ministers of foreign affairs for Germany and France put forward a proposal to strengthen CSDP as part of the initiative to deepen European integration. They returned, inter alia, to the concept of establishment of permanent operational command of the EU, enhancement of common financing of European operations, as well as conducting a review of defensive planning of the member states, including schedules of investment in weapons and military equipment for the purpose of their gradual coordination (European semester on defence capabilities). The majority of postulates was also considered in the Global strategy for foreign and security policy of the European Union presented on 28 June 2016 by the High Representative of the Union for Foreign and Security Policy. The above strategy calls, among other things, for gradual synchronisation and mutual adjustment of national planning cycles in the areas of defence, cybernetic security, terrorism prevention, as well as energy and strategic communication. Although member states were sceptical in its adoption, it was decided to continue works on its operationalisation. It is certain that the Strategy will serve as a basis for the establishment of a document postulating reforms of CSDP. In turn, in its resolution of 13 April 2016, the European Parliament took the initiative to establish the 
European Union of Defence as a panacea to the deepening sense of risk and threat in Europe due to compromised security at the borders of the European Union, mainly in its eastern and southern neighbourhood. In the said proposal, the EP postulates, among other things, creation of European semester of defence evaluating the progress made with regard to budgetary spending of the member states in the area of defence; establishment of a permanent council of ministers of defence; support for NATO's initiative regarding deployment of multinational battalions in the member states or reform of the concept of the EU military groups. The foundation of the European Union of Defence would also be based on common EUNATO projects regarding combating and preventing hybrid hazards and building resilience, cooperation in the area of communication and strategic reaction, operational cooperation, including maritime operations, coordination with regard to cybernetic security and cyber defence, defence capabilities, strengthening of technological, research and industrial base of the defence sector, manoeuvres and building capabilities within security and defence of our partners in the east and south. These ideas are not revolutionary, as they do not go beyond the thus far adopted framework of the CSDP debate and do not involve establishment of the socalled European army. However, our attention should be drawn to the fact that the representatives of France and Germany mention the possibility of an activation of a mechanism of permanent structured cooperation which would enable creation of the defence core of the EU by countries wishing to tighten such a cooperation beyond the mechanisms resulting from the treaty (Terlikowski, 2016, pp. 1-2).

The countries of the Visegrad Group, i.e., Poland, the Czech Republic, Slovakia, and Hungary, used to operate under the influence of the USSR. All of them belong to the European Union and NATO. The country that grew to become the European 'top student' among these countries is Slovakia, which was very consistent in the implementation of reforms leading to its adoption of the euro. The Czech Republic is believed to be the most Eurosceptical country of the EU next to the United Kingdom. However, with the geopolitical position of the Czech Republic, i.e., completely surrounded by allies, such an approach can be afforded. Whereas the latest social-political changes in Poland and Hungary imply a necessity to raise questions regarding the status of implementation of the legal state assumptions in these countries. From political point of view, it will be difficult for Poland to maintain the "yellow jersey" of the leader in Central-Eastern Europe, whose position thus far, especially in the period when it drew Western Europe's attention to the dangerous acts of Russia in Ukraine or Georgia (not only in recent years but also at the time of presidency of Aleksander Kwaśniewski and the late Lech Kaczyński), was strong and stable. The regulations of the EU treaty law are constructed in 
such a way that in the event of a necessity and real threat from the East it will be difficult to call on the principle of solidarity and the above discussed regulations of Common Foreign and Security Policy which - as we have attempted to indicate - do not offer a real, effective guarantee of action in the case of sudden, unforeseen activities of other countries or entities undermining the security of the countries of the EU.

In other words, the states of the EU, particularly those of the so-called 'old Union,' are not prepared to die for Gdańsk, Warsaw or Budapest, or even for Tallinn or Vilnius. If we take into account the prospect of Brexit, the Baltic States are about to lose an important advocate in the EU. Poland, which borders, inter alia, with the Kaliningrad Oblast, Belarus and Ukraine, or Slovakia and Hungary, also with borders with Ukraine, will not be able to ensure their security to the extent required only if, for instance, US soldiers were to be accepted in their territory (as it has recently taken place in Poland), particularly in the light of opening of presidency of Donald Trump with his America First strategy, which in fact probably constitutes a variation of splendid isolation, already well-defined by history. This can have an effect on the potential engagement of NATO in its actions for the security of the Visegrad Group, particularly in the event of a threat from the Russian Federation which during the last several years has been creating situations testing the tolerance of the countries of the NATO and the EU, for instance, by the deployment of Iskandar missiles in the Kaliningrad Oblast or the 'excursions' and 'incidents' with the participation of Russian military aircraft over the Baltic and North Sea, not to mention the activities carried out in the territory of Ukraine. Thus, the thesis that is still valid is that "the transatlantic relations are irreplaceable. It should be the objective of the Union to build an effective and sustainable partnership with the USA which may serve the prosperity of the world" (Malak, 2006, p. 96). It should also be mentioned that within the Visegrad Group, thus far consistent in its approach towards security, there is an evident discrepancy that has been recently expressed in the declaration of Hungarian minister of foreign affairs, Peter Szijjarto, who supported tightening of cooperation with Russia and lifting of the economic sanctions imposed by the EU on Russia, which - in his opinion - are ineffective and since their imposition in 2014, Hungary itself has lost 6.5 billion dollars due to wasted opportunities. "I don't see Russia as a threat to Hungary. I understand and respect that our Polish friends, Baltic friends have another position on that [...]. Russia would not attack any NATO member state. I don't think it would be in Russia's interest” (TVN24, 2017). Moreover, in the same interview the minister of foreign affairs stated that Hungary is already thinking about the terms of extension of the gas agreement with Russia in 2012, 
while simultaneously preparing for the construction of two new nuclear reactors for power plants in Paks (TVN24, 2017).

While analysing the issue of security of the Visegrad Group countries in relation to the European Union, the significance of the principle of solidarity should not be overestimated. This principle - as it is frequently observed in literature - is often violated in the EU. An example is an arbitrary action of Germany and France with regard to Ukrainian-Russian crisis when the two countries undertook measures unwarranted by the EU and without consultation with other member states in a matter that affects interests of the entire Union (Muszyński, 2016, p. 19), or a lack of a consent of the so-called old Union to the proposed energy community, as a consequence of which Western Europe receives gas from Russia at lower rates as compared to Central-Eastern Europe, or a consent to the construction of NordStream 2 gas pipeline which is inconsistent with the EU's energy diversification strategy (Muszyński, 2016, p. 20).

Thus, it is vital for the V4 countries to implement such a policy that would raise the awareness of Western Europe concerning the risk and consist in exerting political pressure on the countries of the so-called old Union (in particular including France and Germany) in order to ensure permanent cooperation with the USA, assume more responsibility for the security and peace in the world as an international organisation and support all actions aimed at constructing real and effective common defence policy for the EU member states where it is possible (as, for instance, subsequent wars in Iraq expressly showed that there are areas where common foreign policy is difficult to agree on, hence, in the light of an obvious discrepancy of interests even of the states belonging to the EU, it is pointless and infeasible). The opinion expressed in source literature is pertinent. It says that "in the context of strategic threats we may say that Europe does not feel them and considers them hypothetically, as it does not anticipate a conflict to arise in this area. It is different when it comes to the United States [...]. An assumption on the possibility of a conflict is continually present in American thinking, while Europeans, both today and in the 1930s tend to manifest - as one may put it - permanent short-sightedness" (Malak, 2006, p. 98).

What should also be mentioned here is the attempt made by the Visegrad Group to intensify defence cooperation within the so-called V4 Defence Cooperation, which practically from the very beginning of its existence has constituted one of the pillars for the functioning of the Group. However, the actual intensification of actions and extension of efforts made within the framework of this cooperation took place after an accession of V4 member states to NATO and the EU. The key document concerning the V4 Defence Cooperation is the Long-term Vision of 
the Visegrad Countries on Deepening their Defence Cooperation published on 14 March 2014 in Visegrad. The vision assumes an effective use of available budgetary and other resources, tightening of cooperation in the region, increasing the security level of the entire Alliance, modernisation of military forces and avoidance of effort duplication of particular countries whilst fully respecting their sovereignty. In practice, the efforts of the Visegrad Group concentrate on three areas: 1) development of capabilities, acquisition of necessary equipment and defence industry; 2) formulation of multinational military units and conducting actions of international character; 3) military education, training and practice.

Development of capabilities and acquisition of necessary military equipment constitutes an essential element of the said cooperation. As a matter of priority, the possibility of cooperation between four, three or two member states of the Visegrad Group is to be considered in relation to obtaining capabilities (means or resources) for the military forces of particular countries. This does not mean rejection of the possibility to use defence system support mechanisms offered by NATO and the EU (e.g., the European Defence Agency). The formation of multinational military units is a legitimate proof of efficiency in the accomplishment of cooperation objectives of the Visegrad Group which are of substantial political significance. The primary form leading towards fulfilment of this task should consist in the establishment of common formations of modular character to be then offered to NATO and the EU as an instrument of implementation of security policy. Interoperability of armed forces, on the other hand, is achieved through proper military education, training and practice within Visegrad Group Military Educational Program (VIGMILEP) (Serowaniec \& Kacała, 2015, pp. 187-188).

It should be added that in the summer of 2017, Hungary is to take over the leadership of the Visegrad Group, with the priority to ensure energy security, unify its position regarding Brexit and the so-called transition to digital economy (TVN24, 2017). Strengthening of Common Foreign and Security Policy as well as a greater engagement in strengthening international security not only lies in the interest of the Visegrad Group countries but also of the entire European Union which currently needs to face Brexit and other new challenges such as globalisation, fight against terrorism, competition with other world economies which exhibit outstanding growth. Current foreign policy of the European Union does not replace foreign policies of particular member states and treaties constitute merely a plane for the agreement of common positions or defining the discrepancies occurring among the EU countries whose foreign policy focuses on their own interests (Wójtowicz, 2016, p. 85). 


\section{References:}

Banaszak, B. (2014). Unia Europejska jako wspólnota wartości, Przeglq̨d Sejmowy, 4, pp. 9-21.

Bień-Kacała, A., \& Serowaniec, M. (2016). Concept of Security and Its Types. In: A. Bień-Kacała et al. (Eds.), Security in V4 Constitutions and Political Practices (pp. 15-21). Toruń: Wydawnictwo Naukowe UMK.

TVN24 (2017). Węgry chcq ściślejszej współpracy z Rosjq. Sankcje bezużyteczne. http://www. tvn24.pl (January 27). Retrieved from: http://www.tvn24.pl/wiadomosci-ze-swiata,2/ wegry-chca-scislejszej-wspolpracy-z-rosja-i-lepszych-stosunkow-z-usa,710749.html.

Long-term Vision of the Visegrad Countries on Deepening their Defence Cooperation, published on 14 March 2014 in Visegrad. Retrieved from: www.visegradgroup.eu/calendar/ 2014-03-14-ltv.

Malak, K. (2006). Unia Europejska w europejskim kompleksie bezpieczeństwa. In: M. Stolarczyk (Ed.), Unia Europejska i Polska wobec dylematów integracyjnych na poczq̨tku XXI wieku (pp. 83-98). Toruń: Wydawnictwo Adam Marszałek.

Milczarek, D. (2006). Dylematy polityki zagranicznej i bezpieczeństwa Polski jako państwa członkowskiego Unii Europejskiej. In: J.M. Fiszer (Ed.), Polska polityka integracyjna po przystapieniu do Unii Europejskiej (pp. 199-220). Warszawa: Dział Wydawnictw ISP PAN.

Muszyński, M. (2016). Solidarność międzynarodowa: między polityką a prawem, Prawo i Więź, 3(17), pp. 7-21.

Serowaniec, M., \& Kacała T. (2015). Międzyparlamentarny wymiar współpracy w ramach Grupy Wyszehradzkiej, Studia z zakresu nauk prawnoustrojowych. Miscellanea, 5, pp. 179-191.

Szmulik, B. (2012). Zagadnienia ogólne. In: B. Szmulik, \& M. Paździor (Eds.), Instytucje bezpieczeństwa narodowego (pp. 1-14). Warszawa: C.H. Beck.

Terlikowski, M. (2016). Konsekwencje Brexitu dla UE: polityka bezpieczeństwa po szczycie NATO, Biuletyn PISM, 43, pp. 1-2.

Witkowska-Chrzczonowicz, K.M. (2014). Dynamika rozwoju Rady Europejskiej w systemie instytucjonalnym Unii Europejskiej. Studium prawno-ustrojowe. Toruń: Towarzystwo Naukowe Organizacji i Kierownictwa - Stowarzyszenie Wyższej Użyteczności „Dom Organizatora”.

Witkowska-Chrzczonowicz, K.M. (2016). Kategoria bezpieczeństwa w prawie i praktyce funkcjonowania UE. In: A. Bień-Kacała et al. (Eds.), Kategoria bezpieczeństwa w regulacjach konstytucyjnych i praktyce ustrojowej państw Grupy Wyszehradzkiej (pp. 41-57). Toruń: Wydawnictwo Naukowe UMK.

Wójtowicz, K. (2016). Polityka zagraniczna Unii Europejskiej a kompetencje państw członkowskich. In: J. Galster, \& A. Szczerba-Zawada (Eds.), Polityka zagraniczna Unii Europejskiej. Prawo i praktyka (pp. 73-85). Warszawa: Instytut Wydawniczy EuroPrawo. 